\title{
Når postnummeret har betydning for overvekt
}

\author{
Forskning viser at det er større sannsynlighet for å bli overvektig hvis man bor på bygda enn hvis man bor \\ i byen. For å redusere denne ulikheten må vi avdekke hvordan stedsspesifikke kulturelle og sosiale miljøer \\ har innvirkning på helseatferden vår. Dette fordrer en langt mer helhetlig forskningstilnærming til overvekts- \\ problematikken enn det vi hittil har sett.
}

\author{
Reidun Heggem \\ reidun.heggem@bygdeforskning.no \\ Maja Farstad \\ Bjørn Egil Flø
}

Vi står overfor en fedmeepidemi. På verdensbasis er tallet på overvektige mer enn fordoblet i løpet av de siste 30 årene. $35 \%$ av alle voksne over 20 år ble i 2008 karakterisert som overvektige av Verdens helseorganisasjon (1). I dag resulterer overvekt og fedme i flere dødsfall enn det undervekt gjør (1). Videre tyder studier på at overvektsproblematikken er større i rurale enn i urbane områder (2-6). Forskere har slitt med å finne årsakene til denne forskjellen, og i lys av dette argumenterer vi her for flerfaglig samarbeid, inkludert samfunnsvitenskapelige tilnærminger til helse og helseatferd.

Dersom vi inntar flere kalorier enn vi forbrenner, legger vi på oss. Samtidig vet vi at årsakene til overvekt og fedme er sammensatte, komplekse og individuelt betinget. Resultater fra tidligere forskning peker mot at økningen i antall overvektige kan skyldes interaksjonen mellom genetiske faktorer og miljøfaktorer, ved at flere genetiske varianter interagerer med ulike risikomiljøer $(2,7)$. Trolig er

det likevel miljøendringer, og ikke først og fremst genetiske endringer, som er årsak til den betydelige økningen i løpet av de siste tiårene (8). Miljøforhold manifesterer seg i folks helseatferd - uavhengig av om denne er bevisst eller ikke - og på dette området mener vi at samfunnsvitenskapelig forskning kan komme med viktige bidrag i den videre kampen mot overvekt generelt, og spesielt $\mathrm{i}$ arbeidet med å eliminere ulikhetene mellom bygd og by.

\section{Komposisjonelle og kontekstuelle forklaringer}

I løpet av det siste tiåret er det publisert flere norske og internasjonale studier $(2,4,6,9$, 10) som viser at det er en sammenheng mellom bosted og overvekt. Forekomsten av overvekt er høyere i rurale enn i urbane strøk. Flere studier påpeker at forklaringsfaktorene bak disse forskjellene fremdeles er usikre, og at det er helt avgjørende å identifisere dem. Forskjeller i overvekt kan forklares enten ut fra sosiodemografiske karakteristika ved innbyggerne i bestemte områder såkalte komposisjonelle forklaringer, eller ut fra trekk ved området de lever i - såkalte kontekstuelle forklaringer $(11,12)$. Teoretisk polarisering bør imidlertid unngås i og med at dårlig helse og overvekt $i$ et område like gjerne kan skyldes både variabler knyttet til menneskene og variabler knyttet til stedet.

Folk i rurale områder har i mange tilfeller lavere inntekt og lavere utdanningsnivå enn folk i urbane strøk, og lav skår på disse sosiodemografiske faktorene peker ofte mot livsstiler som i mindre grad er helsefremmende $(5,13)$. Flere studier indikerer imidlertid at ruralt bosted i seg selv utgjør en risikofaktor for overvekt, også når man kontrollerer for sentrale komposisjonelle variabler $(4,6,10)$

Mens det stadig kontrolleres for komposisjonelle variabler i kvantitative analyser, er det vanskeligere å inkludere potensielle kontekstuelle forklaringsfaktorer. Mulige kontekstuelle forklaringer trekkes ofte frem når de komposisjonelle variablene ikke gir tilstrekkelig forklaring, men førstnevnte blir ofte presentert kun som rene spekulasjoner. Et eksempel her er undersøkelsen utført av Svensson og medarbeidere (9), som foreslår at den geografiske variasjonen i kroppsmasseindeks muligens skyldes ulike urbane og rurale forskjeller i livsstil og ulik eksponering for et ideal om å være tynn. En annen spekulasjon er at det finnes kulturelt baserte spisemønstre på bygda som preges av store porsjoner og mange måltider med energiladet mat, såkalt «country cooking» (14), som skiller seg fra spisemønstre i mer urbane strøk. Opprettholdelse av tidligere generasjoners etablerte energiinntak kombinert med endrede aktivitetsvaner hos den rurale befolkningen, som for eksempel mindre fysisk arbeid og mer biltransport, utgjør en annen mulig forklaring (4).

Vi vet at forestillinger om det rurale påvirker politiske så vel som individuelle handlingsvalg. Synet på, og holdninger til, det rurale påvirker også samfunnets evne til å se utfordringene som utvikler seg samt hvordan negative trender håndteres og forebygges. På den ene side eksisterer en forestilling av bygda som marginalisert (15), noe som kan skape et grunnlag for en generell, kulturell motstand mot helsemyndighetene og andres offisielle ekspertkunnskap $(16,17)$. Rådene fra helsemyndighetene blir da oppfattet som et angrep på egne verdier og livsstil. På den annen side kan forestillingen om den rurale idyllen $(18,19)$ føre til en naiv tro på at folk på bygda er sunnere enn i byene.

Helseforskningens spekulasjoner, så vel som våre ruralsosiologiske spekulasjoner, tydeliggjør behovet for mer kunnskap om hva som har betydning for folks helseatferd samt hvordan de legitimerer og forklarer sine livsstilvalg sett opp mot de ulike diskursene for riktig og sunn helseatferd (20).

\section{Samfunnsvitenskapelig teori}

Bourdieus teorier kan være nyttige verktøy for å belyse bostedets betydning (kontekstuelle forklaringer) for overvektsproblematikken (21). Begrepsparet habitus og felt viser til hvordan individene, gjennom stedlig kulturell innsosialisering, er i besittelse av ulike basisdisposisjoner. Disse disposisjonene er kroppsliggjort - de er ubevisste og ikke gjort til gjenstand for refleksjon og ligger til grunn for vår tenkning og praksis. Den vanemessige praksisen, det vi konkret gjør med kroppen, læres primært gjennom sosialisering i familien, men også gjennom utdanning og i yrkeslivet. Smaken, eller det vi foretrekker, kan forstås som en kroppsliggjøring av ulike klassekulturer. Hvilken type mat vi spiser, hva vi interesserer oss for, og hvor mye vi investerer i helse, vil således være avhengig av vår habitus (21). Når det gjelder forskjellene i overvekt mellom by og bygd, vil det være hensiktsmessig å studere ulike former for habitus som eksisterer og utvikles i byog bygdekontekster.

\section{Tverrfaglig tilnærming}

I tidsskriftet Forskning synliggjøres brytningen mellom fagdisipliner når det gjelder spørsmålet om hvordan overvektsproble- 

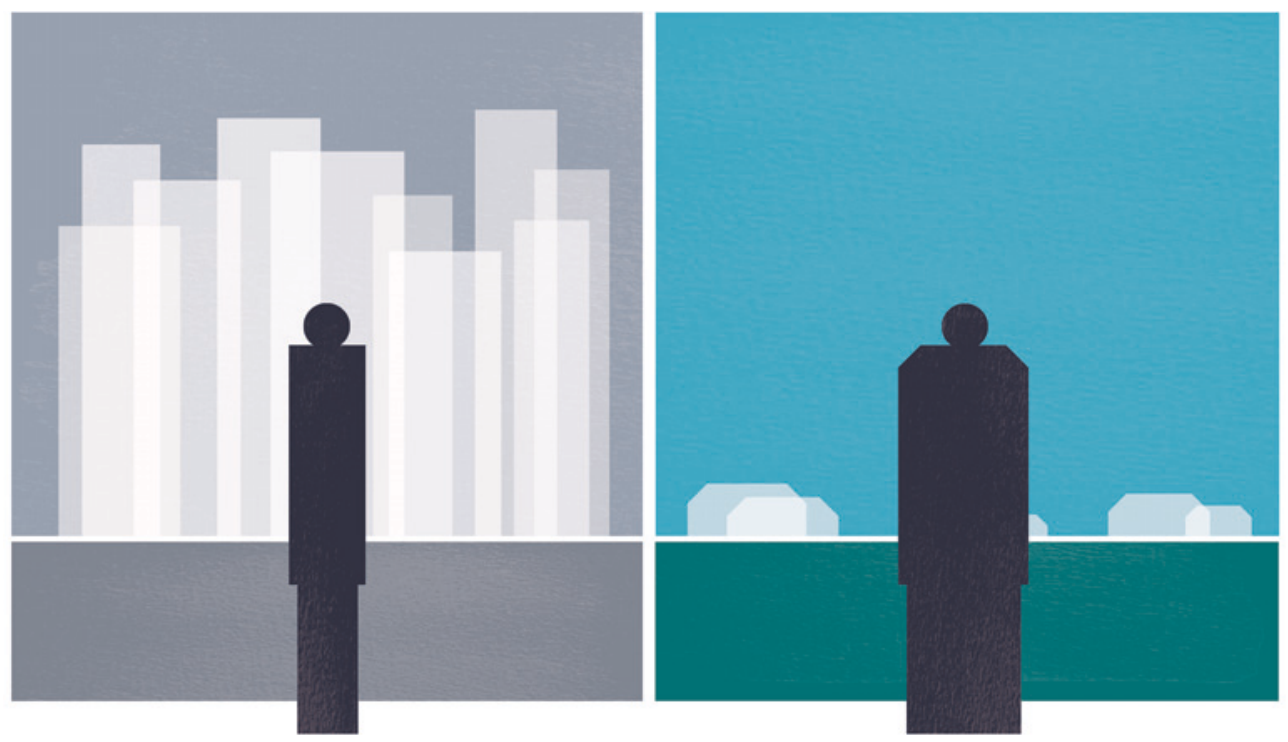

Illustrasjon $\odot$ Superpop

matikken kan bekjempes (22). På den ene side sier professor i ernæringsvitenskap ved Universitetet i Oslo, Christian A. Drevon, at «økt kunnskap om sammenhenger mellom ernæring, fysisk aktivitet og overvekt er den eneste veien ut av fedmeproblemet». På den annen side poengterer sosiolog og forsker ved Nasjonalt kompetansesenter for læring og mestring ved Aker universitetssykehus, Heidi Kvalvaag: «Vi har aldri visst så mye om ernæring og fysiologi, likevel er vi fetere enn noensinne. Vi trenger en annen kunnskap.»

Det er åpenbart at man ikke har funnet et entydig svar på hvordan overvekt kan unngås. Det finnes for eksempel mange og til dels motstridende diskurser om hva som er et gunstig kosthold med tanke på å unngå overvekt (23). Samtidig er det tydelig at kunnskap om sammenhengen mellom ernæring, fysisk aktivitet og overvekt på ingen måte er tilstrekkelig for å komme overvektsproblematikken til livs. Den velkjente uoverensstemmelsen mellom kunnskap og praksis kan ikke forbigås, og det blir derfor essensielt å se på faktorer som påvirker våre handlingsvalg, med tanke på målet om en sunn helseatferd $\mathrm{i}$ befolkningen. For å få svar på forskjellene man finner langs den rural-urbane dimensjonen, må man inkludere inngående og kritisk samfunnsforskning med vekt på sosiale, kulturelle og strukturelle dynamikker. Det er viktig å forstå ulike geografisk baserte habituser for å finne riktig kommunikasjonsstrategi for å nå målgruppen. Forskning så langt peker mot at kulturelle forhold er av betydelig relevans, og disse kan vanskelig fanges opp $i$ et spørreskjema. $\mathrm{Vi}$ argumenterer for at en helhetlig samfunnsvitenskapelig og tverrfaglig tilnær- ming vil være vesentlig for å øke kunnskapen om helseatferd.

\section{Reidun Heggem (f. 1972)}

er forsker og ph.d.-student i sosiologi ved Norsk senter for bygdeforskning/Norges teknisk-naturvitenskapelige universitet.

Forfatter har fylt ut ICMJE-skjemaet og oppgir ingen interessekonflikter.

\section{Maja Farstad (f. 1980)}

er forsker og ph.d.-student i sosiologi ved Norsk senter for bygdeforskning/Norges teknisk-naturvitenskapelige universitet.

Forfatter har fylt ut ICMJE-skjemaet og oppgir ingen interessekonflikter.

\section{Bjørn Egil Flø (f. 1964)}

er forsker og ph.d.-student i sosiologi ved Norsk senter for bygdeforskning/Norges teknisk-naturvitenskapelige universitet.

Forfatter har fylt ut ICMJE-skjemaet og oppgir ingen interessekonflikter.

\section{Litteratur}

1. World Health Organization. Obesity and overweight. Fact sheet Nº311. Oppdatert mars 2013. www.who.int/mediacentre/factsheets/fs311/en/ (18.6.2014).

2. Grøholt EK, Stigum H, Nordhagen R. Overweight and obesity among adolescents in Norway: cultural and socio-economic differences. J Public Health (Oxf) 2008; 30: 258-65.

3. Heyerdahl N, Aamodt G, Nordhagen R et al. Overvekt hos barn - hvilken betydning har bosted? Tidsskr Nor Legeforen 2012; 132: 1080-3.

4. Biehl A, Hovengen R, Grøholt EK et al. Adiposity among children in Norway by urbanity and maternal education: a nationally representative study. BMC Public Health 2013; 13: 842

5. Fiscella K, Williams DR. Health disparities based on socioeconomic inequities: implications for urban health care. Acad Med 2004: 79: 1139-47.

6. Lutfiyya MN, Lipsky MS, Wisdom-Behounek J et al. Is rural residency a risk factor for overweight and obesity for U.S. children? Obesity (Silver Spring) 2007; 15: 2348-56.

7. Sørensen TIA. The genetics of obesity. Metabolism 1995; 44 (Suppl 3): 4-6.

8. Helsetilstanden i Norge. Rapport nr. 2/2010. Oslo: Nasjonalt folkehelseinstitutt, 2010

9. Svensson E, Reas DL, Sandanger I et al. Urbanrural differences in BMI, overweight and obesity in Norway (1990 and 2001). Scand J Public Health 2007: 35: 555-8.

10. Phillips CD, McLeroy KR. Health in rural America: remembering the importance of place. Am J Public Health 2004; 94: 1661-3.

11. Sobal J, Troiano RP. Frongillo EA Jr. Rural-urban differences in obesity. Rural Sociol 1996: 61: 289-305.

12. Frohlich KL, Corin E, Potvin LA. Theoretical proposal for the relationship between context and disease. Sociol Health Illn 2001; 23: 776-97.

13. Mayor S. Children living near fast food outlets in England are more likely to be overweight, study shows. BMJ 2014; 348 (feb14 1): g1557.

14. Befort CA, Nazir N, Perri MG. Prevalence of obesity among adults from rural and urban areas of the United States: findings from NHANES (2005-2008). J Rural Health 2012; 28: 392-7.

15. Bell D. Anti-idyll: rural horror. I: Cloke P, Little J, red. Contested countryside cultures: otherness, marginalisation and rurality. London: Routledge, 1997: 94-108.

16. Krange O, Skogen K. Kodebok for den intellektuelle middelklassen. Nytt Norsk Tidsskrift 2007 3: 227-42

17. Willis PE. Learning to labor: how working class kids get working class jobs. New York: Columbia University Press, 1977.

18. Little J, Austin P. Women and the rural idyll. J Rural Stud 1996; 12: 101-11.

19. Cloke P. Milbourne P. Deprivation and lifestyles in rural Wales. J Rural Stud 1992; 8: 359-71.

20. Higgs $G$. Investigating trends in rural health outcomes: a research agenda. Geoforum 1999; 30 : 203-21.

21. Bourdieu P. Distinction. Cambridge, MA: Harvard University Press, 1994.

22. Moen S. Hva gjør vi med fedmen? Bladet Forskning 2005; 1 www.forskningsradet.no/ bladetforskning/Nyheter/Hva gjor vi med fedmen/1250810530053 (18.6.2014)

23. Klemsdal TO. Kosthold, kolesterol og karbohydrater. Tidsskr Nor Legeforen 2013; 133: 184-6. 